\title{
Pengaruh Penambahan Buah Asam (Tamarindus indica L.) Terhadap Karakteristik Loloh Don Teter (Solanum erianthum)
}

\section{The Effect of Additional of Tamarind Fruit (Tamarindus indica L.) on the Characteristics of Loloh Teter Leaf (Solanum erianthum)}

\author{
I Wayan Ryantama Swastika Braja ${ }^{1}$, I Dewa Gde Mayun Permana ${ }^{1 *}$, I Ketut Suter ${ }^{1}$ \\ Program Studi Ilmu dan Teknologi Pangan, Fakultas Teknologi Pertanian, Universitas Udayana \\ Kampus Bukit Jimbaran, Badung-Bali \\ *Penulis korespondensi: IDG Mayun Permana, Email: mayunpermana@unud.ac.id
}

\begin{abstract}
Loloh teter leaf is one of the traditional drinks in Bali, it made from raw material of teter leaf and other matter such as tamarind fruit, sugar and salt. The study aims to determine the effect of additional tamarind fruit (Tamarindus indica L.) to produce Loloh Teter leaf (Solanum erianthum) with the best characteristics. The experimental design used was a Completely Randomized Design (CRD) with the addition of tamarind fruit treatment consisting of 6 levels, namely : $0 \%, 0.5 \%, 1 \%, 1.5 \%, 2 \%$ and $2.5 \%$. The treatment was repaeated 3 times for abtaining obtained 18 experimental units. The data obtained were analyzed by variance and if the treatment had significant effect followed by Duncan Multiple Range Test (DMRT). The results of this study indicate that the treatment of tamarind fruit addition has a very significant effect $(\mathrm{P}<0,01)$ on total phenolics, total flavonoids, vitamin $\mathrm{C}$, antioxidant activity, total solids, color (hedonic test) and taste (scoring test). The best treatment in this study was the addition of $2,5 \%$ tamarind fruit with the total phenolics $0.86 \mathrm{GAE} / 100 \mathrm{ml}$, total flavonoids $0.48 \mathrm{QE} / 100 \mathrm{ml}$, vitamin C $26.39 \mathrm{mg} / 100 \mathrm{ml}$, antioxidant activity $47.05 \%$ with $\mathrm{IC}_{50}$ valued $271,382.73 \mathrm{ppm}$, total solids $7.44 \%$, the color is usual as well as, the aroma is rather liked, the teste is sour and rather liked and overall acceptance is rather liked.
\end{abstract}

Keywords: loloh, teter leaf, tamarind fruit, traditional drinks

\section{PENDAHULUAN}

Tanaman teter (Solanum erianthum) merupakan tanaman yang memiliki ciri-ciri yaitu tinggi pohon bisa mencapai 2 meter hingga 8 meter, pada batang dan daunnya terdapat bulu halus, memiliki ketebalan batang sekitar 2-5 cm dan panjang daun $12-37 \mathrm{~cm}$, memiliki bunga dan buahnya berawarna kuning ketika sudah matang (Anon, 2017). Tanaman teter berasal dari Amerika Tengah dan Meksiko, namun banyak tersebar di daerah Afrika Barat, Asia Tenggara dan Australia (Modise dan Mogotsi, 2008). Menurut Modise dan Mogotsi (2008) bagian daun pada tanaman teter memiliki kandungan komponen bioaktif yang digunakan dalam bidang farmasi sebagai anti-inflamasi, rebusan daun teter di Afrika Barat sering digunakan sebagai obat diuretik, menyembuhkan penyakit malaria, kusta, penyakit kelamin dan merangsang fungsi hati. Essien et al. (2012) 
juga melaporkan bahwa daun teter memiliki kandungan minyak esensial yang dapat digunakan sebagai obat tradisional khususnya dalam mengobati penyakit kulit dan penyakit lambung.

Priyadharsini et al. (2013) melaporkan bahwa kandungan yang terdapat dalam daun tanaman teter yaitu alkaloid, flavonoid, fenolik, tanin, saponin, steroid, terpenoid yang berfungsi sebagai antioksidan. Menurut Mahadev et al. (2015) kandungan senyawa fitokimia dalam daun teter yaitu total fenol $30,68 \mathrm{mg}$ GAE/g, total flavonoid $53,85 \mathrm{mg}$ $\mathrm{RE} / \mathrm{g}$, uji total antioksidan 31,66 GAE/g. Aktivitas antioksidan daun teter yang dianalisis dengan nilai $\mathrm{IC}_{50}$ yaitu $0,14 \mathrm{mg} / \mathrm{ml}$ lebih tinggi dibandingkan dengan bagian buahnya yaitu $0,17 \mathrm{mg} / \mathrm{ml}$ (Mahadev et al., 2015). Priyadharsini et al. (2013) juga melaporkan nilai $\mathrm{IC}_{50}$ pada ekstrak daun teter dengan pelarut aseton sebesar $0,112 \mathrm{mg} / \mathrm{ml}$ lebih besar dibandingkan dengan batang teter yaitu sebesar $0,216 \mathrm{mg} / \mathrm{ml}$.

Masyarakat Bali umumnya telah banyak mengkonsumsi ekstrak tumbuhan sebagai obat dengan menggunakan konsep Usada Taru Pramana (Suryadarma, 2005). Daun teter banyak dimanfaatkan oleh masyarakat Bali menjadi loloh. Loloh merupakan minuman tradisional Bali yang biasanya terbuat dari bagian daun tanaman dan memiliki efek fisiologis bagi tubuh. Salah satu produsen loloh don teter yaitu Kelompok
Wanita Tani (KWT) Dwi Tunggal Putri di Desa Taro, Tegalalang, Gianyar. Pembuatan loloh don teter menggunakan bahan baku daun teter, selain itu juga menggunakan bahan tambahan seperti buah asam, gula pasir dan garam untuk memperbaiki cita rasa. Loloh don teter memiliki rasa yang khas yaitu rasa asam, manis dan asin. Namun saat ini formulasi pembuatan loloh don teter di masyarakat khususnya KWT Dwi Tunggal Putri masih menggunakan perasaan atau perkiraan sehingga akan mempengaruhi kualitas loloh don teter yang diproduksi. Berdasarkan hasil wawancara dengan Ibu Wirati (Ketua KWT Dwi Tunggal Putri) penambahan buah asam yang biasanya digunakan dalam pembuatan loloh don teter hanya perkiraan yaitu 7,5 gram per $500 \mathrm{ml}$ atau dengan konsentrasi $1,5 \%$.

Penambahan buah asam selain dapat mempengaruhi cita rasa juga dapat meningkatkan aktivitas antioksidan pada loloh don teter. Menurut Ferrara (2005) bahwa buah asam mempunyai aktivitas antibakteri, antikapang, efek hipoglikemik, efek hipokolesterolemik, anti-peradangan dan aktivitas antioksidan. Wijayanti et al. (2016) melaporkan semakin banyak konsentrasi buah asam maka aktivitas antioksidan yang dihasilkan cenderung meningkat, hal itu disebabkan karena buah asam mengandung senyawa seperti tanin, flavonoid dan senyawa fenol yang memiliki kemampuan sebagai antioksidan. Namun, penambahan konsentrasi 
buah asam yang meningkat juga akan mempengaruhi segi organoleptik yang dapat diterima oleh konsumen. Purnomo et al. (2018) melaporkan bahwa konsentrasi buah asam yang berbeda akan menghasilkan karakteristik yang berbeda juga meliputi warna, rasa, aroma dan penerimaan keseluruhan. Penelitian terkait loloh don teter belum banyak dilakukan sehingga belum ada standar yang pasti terhadap formulasi loloh don teter. Penelitian ini bertujuan untuk mengetahui pengaruh penambahan buah asam dan mengetahui penambahan buah asam yang tepat untuk menghasilkan loloh don teter dengan karakteristik terbaik.

\section{METODE PENELITIAN}

\section{Tempat dan Waktu}

Penelitian ini dilakukan di Laboratorium Analisis Pangan, Laboratorium Pengolahan Pangan, Laboratorium Mikrobiologi Pangan dan Laboratorium Rekayasa Proses dan Pengendalian Mutu Fakultas Teknologi Pertanian Universitas Udayana Gedung Agrokomplek, Jalan PB. Sudirman, Denpasar, Bali. Penelitian ini dilakukan dari bulan Januari sampai dengan bulan Maret 2020.

\section{Bahan dan Alat}

Bahan yang digunakan dalam penelitian ini adalah daun teter dengan kriteria daun berwarna hijau tua tepatnya daun ketiga di bawah pucuk sampai daun kedelapan yang diperoleh di Banjar Taro Kelod, Desa Taro, Gianyar, buah asam, gula (Gulaku), garam (Dolpin) yang diperoleh dari Pasar Badung, air mineral (Aqua), kemasan botol plastik $60 \mathrm{ml}$, kertas label, alumunium foil, tissue, aquades, etanol (Merck), metanol (Merck), reagen Folin-Ciocalteu (Merck), $\mathrm{NaNO}_{2} 5 \%$ (Merck), $\mathrm{AlCl}_{3} 10 \%$ (Merck), $\mathrm{NaOH}$ (Merck), $\mathrm{Na}_{2} \mathrm{CO}_{3}$ (Merck), 2,2-diphenyl-1-picrylhydrazyl (DPPH) (Sigma), reagen asam galat (Merck), reagen kuarsetin (Sigma), reagen asam askorbat (Merck), asam fosfat (Merck), sodium fosfat (Merck) dan ammonium molibdat (Merck).

Alat yang digunakan dalam penelitian ini adalah spektrofotometer (Genesys 10S UVU15), timbangan analitik (Shimadzu ATY224), tabung reaksi (pyrex), tabung sentrifius, gelas ukur (pyrex), labu erlenmeyer (pyrex), pipet tetes (pyrex), pipet mikro (socorex), pipet volume (pyrex), rak tabung, vortex (Maxi Mix II Type 367000), labu takar (pyrex), cawan porselin, corong, oven, spatula/sutil, kompor (Rinnai), gunting, pisau, waterbath (Memmert), blender (Miyako), dan sentrifius (Damon /IEC Division).

\section{Rancangan Percobaan}

Percobaan ini menggunakan rancangan acak lengkap (RAL) dengan perlakuan adalah penambahan konsentrasi buah asam (P). Persentase penambahan buah asam berdasarkan volume total air $(500 \mathrm{ml})$ yang digunakan. Perlakuan terdiri dari 6 level 
sebagai berikut: P0 (konsentrasi buah asam 0\%), P1 (konsentrasi buah asam 0,5\%), P2 (konsentrasi buah asam 1\%), P3 (konsentrasi buah asam 1,5\%), P4 (konsentrasi buah asam 2\%), P5 (konsentrasi buah asam 2,5\%)

Perlakuan ini diulang sebanyak 3 kali sehingga diperoleh 18 unit percobaan. Data yang diperoleh dari hasil penelitian dianalisis lebih lanjut dengan sidik ragam dan apabila perlakuan berpengaruh terhadap variabel maka akan dilanjutkan dengan uji Duncan Multiple Range Test (DMRT) (Steel dan Torrie, 1993).

Pelaksanaan Penelitian Pembuatan Loloh Don Teter

Proses pembuatan loloh don teter menggunakan bahan baku daun teter dengan formulasi seperti Tabel 1. Daun teter dicuci hingga bersih dengan menggunakan air mengalir. Kemudian daun teter ditiriskan dan ditimbang sebanyak 25 gram. Ditambahkan air sebanyak $450 \mathrm{ml}$. Kemudian dihancurkan menggunakan blender selama 40 detik. Disisi lain dilakukan proses pengolahan bahan tambahan yang dilakukan yaitu buah asam sesuai perlakuan $(0 \%, 0,5 \%, 1 \%, 1,5 \%, 2 \%$, 2,5\%), ditambahkan gula 30 gram dan garam 5 gram. Selanjutnya dilarutkan dengan air hangat $\left(40^{\circ} \mathrm{C}\right)$ sebanyak $50 \mathrm{ml}$ dan diaduk hingga homogen. Setelah itu, dicampurkan daun teter yang sudah diblender dengan bahan tambahan dan kemudian disaring.

Tabel 1. Formulasi pembuatan loloh don teter

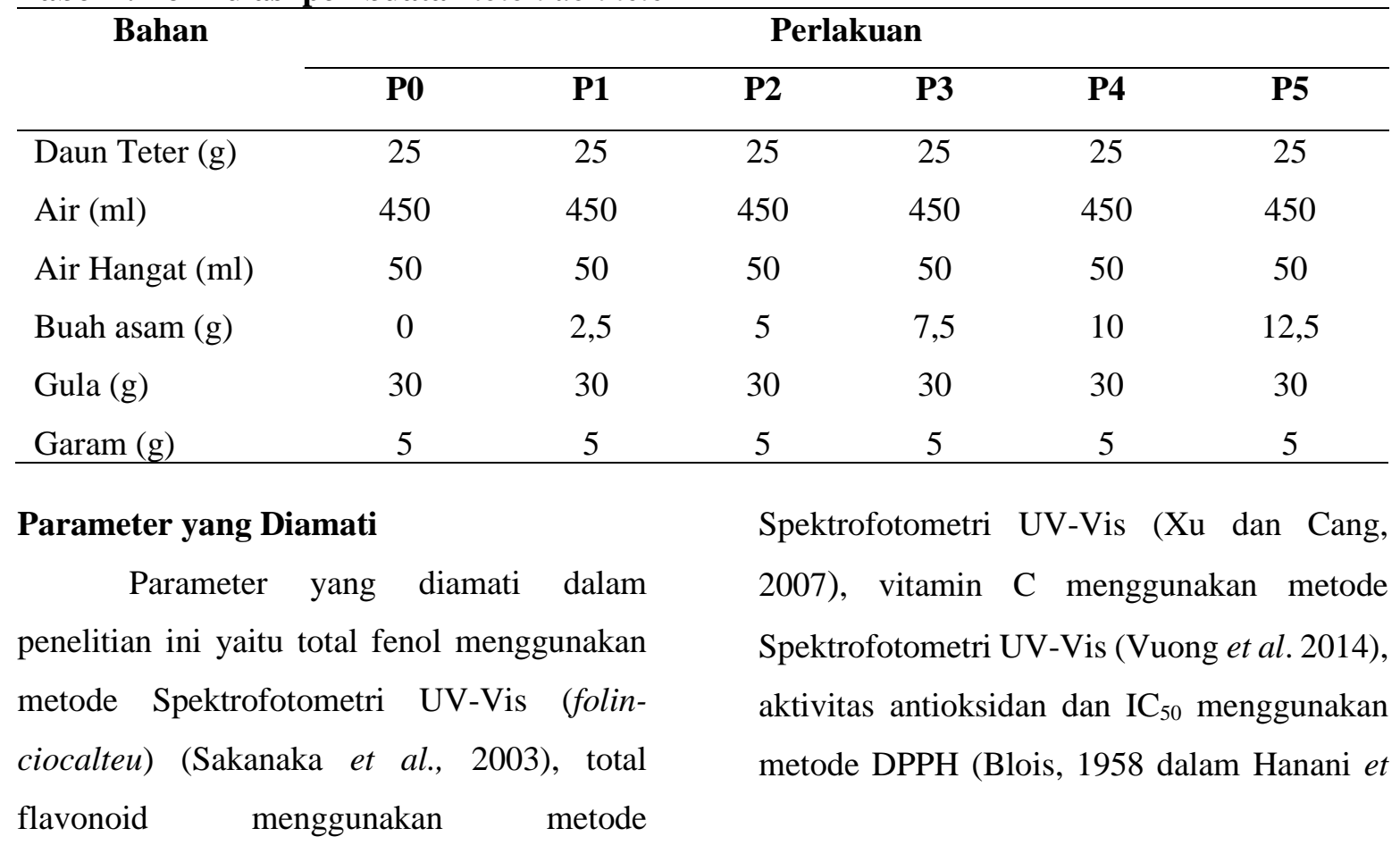


al., 2005), total padatan (SNI 19-0428-1989)

dan sifat sensoris (Soekarto, 1985).

\section{HASIL DAN PEMBAHASAN}

Hasil analisis total fenol, total flavonoid, vitamin $\mathrm{C}$, aktivitas antioksidan dan total padatan dari loloh don teter dapat dilihat pada Tabel 2.

\section{Total Fenol}

Hasil sidik ragam menunjukan bahwa pengaruh penambahan buah asam berpengaruh sangat nyata $(\mathrm{P}<0,01)$ terhadap total fenol loloh don teter. Total fenol loloh don teter pada perlakuan berkisar antara 0,55 mgGAE/100ml sampai dengan 0,86 mgGAE/100ml dapat dilihat pada Tabel 2. Total Fenol tertinggi terdapat pada perlakuan P5 (konsentrasi buah asam 2,5\%) dan terendah terdapat pada perlakuan P0 (konsentrasi buah asam 0\%). Semakin banyak penambahan buah asam maka total fenol yang terkandung dalam loloh don teter juga meningkat.

Menurut Wijayanti et al. (2016) peningkatan fenol akibat penambahan proporsi asam jawa ini disebabkan oleh adanya kandungan tanin, flavonoid dan senyawa fenol lainnya yang terdapat pada buah asam. Sudjaroen et al. (2005) juga melaporkan bahwa senyawa fenolik yang terdapat pada buah asam yaitu proanthcyanidins, catechin, procyanidin, epicatechin, taxifolin, apigenin, eriodictyol, luteolin dan naringenin. Hal ini didukung juga dengan penelitian yang dilakukan oleh (Septiana, 2014) dimana total fenol pada minuman kunyit asam meningkat seiring dengan penambahan proporsi buah asam.

Tabel 2. Nilai rata-rata total fenol, total flavonoid, vitamin $\mathrm{C}$, aktivitas antioksidan dan total padatan loloh don teter.

\begin{tabular}{cccccc}
\hline $\begin{array}{c}\text { Perlakuan } \\
\text { Buah Asam }\end{array}$ & $\begin{array}{c}\text { Total Fenol } \\
(\mathrm{mg} \text { GAE/100 } \\
\mathrm{ml})\end{array}$ & $\begin{array}{c}\text { Total Flavonoid } \\
(\mathrm{mg} \mathrm{QE} / 100 \mathrm{ml})\end{array}$ & $\begin{array}{c}\text { Vitamin C } \\
(\mathrm{mg} / 100 \mathrm{ml})\end{array}$ & $\begin{array}{c}\text { Aktivitas } \\
\text { Antioksidan } \\
(\%)\end{array}$ & $\begin{array}{c}\text { Total Padatan } \\
(\%)\end{array}$ \\
\hline P0 $(0 \%)$ & $0,55 \pm 0,035 \mathrm{e}$ & $0,21 \pm 0,0069 \mathrm{f}$ & $23,00 \pm 0,12 \mathrm{f}$ & $32,28 \pm 0,49 \mathrm{f}$ & $6,45 \pm 0,09 \mathrm{e}$ \\
P1 $(0,5 \%)$ & $0,62 \pm 0,023 \mathrm{~d}$ & $0,29 \pm 0,0074 \mathrm{e}$ & $24,25 \pm 0,10 \mathrm{e}$ & $35,68 \pm 0,54 \mathrm{e}$ & $7,02 \pm 0,02 \mathrm{~d}$ \\
P2 (1\%) & $0,67 \pm 0,014 \mathrm{~cd}$ & $0,34 \pm 0,0036 \mathrm{~d}$ & $24,85 \pm 0,10 \mathrm{~d}$ & $37,23 \pm 0,12 \mathrm{~d}$ & $7,16 \pm 0,01 \mathrm{c}$ \\
P3 (1,5\%) & $0,73 \pm 0,027 \mathrm{c}$ & $0,39 \pm 0,0035 \mathrm{c}$ & $25,32 \pm 0,12 \mathrm{c}$ & $39,16 \pm 0,70 \mathrm{c}$ & $7,24 \pm 0,04 \mathrm{~b}$ \\
P4 (2\%) & $0,80 \pm 0,038 \mathrm{~b}$ & $0,44 \pm 0,0057 \mathrm{~b}$ & $25,70 \pm 0,12 \mathrm{~b}$ & $43,33 \pm 0,35 \mathrm{~b}$ & $7,36 \pm 0,01 \mathrm{a}$ \\
P5 (2,5\%) & $0,86 \pm 0,046 \mathrm{a}$ & $0,48 \pm 0,0086 \mathrm{a}$ & $26,39 \pm 0,23 \mathrm{a}$ & $47,05 \pm 0,62 \mathrm{a}$ & $7,44 \pm 0,02 \mathrm{a}$ \\
\hline
\end{tabular}

Keterangan: Nilai rata-rata yang diikuti oleh huruf yang berbeda pada kolom yang sama menunjukan perlakuan berbeda nyata $(\mathrm{P}<0,05)$. 


\section{Total Flavonoid}

Hasil sidik ragam menunjukan bahwa pengaruh penambahan buah asam berpengaruh sangat nyata $(\mathrm{P}<0,01)$ terhadap total flavonoid pada loloh don teter. Total flavonoid pada perlakuan berkisar antara 0,21 mgQE/100ml sampai dengan 0,48 mgQE/100ml dapat dilihat pada Tabel 2. Total flavonoid tertinggi terdapat pada perlakuan P5 (konsentrasi buah asam 2,5\%) dan terendah pada perlakuan P0 (konsentrasi buah asam $0 \%)$.

Daging buah asam mengandung senyawa flavonoid dan tanin dimana kedua senyawa tersebut dapat menimbulkan efek analgesik dan antiinflamasi (Bandawane et al. 2013). Menurut Akmarina (2018) melaporkan bahwa kandungan total flavonoid dari daging buah asam yaitu sebesar 19,35 mg QE/g. Selain itu, total flavonoid yang terkandung dalam loloh don teter juga berasal dari daun teter. Menurut Babalola (2016) menyatakan bahwa kandungan total flavonoid daun teter yaitu sebesar 11,47 mg QE/g. Berdasarkan penelitian tersebut semakin banyak penambahan buah asam maka semakin tinggi juga total flavonoid loloh don teter.

\section{Vitamin C}

Hasil sidik ragam menunjukan bahwa pengaruh penambahan buah asam berpengaruh sangat nyata $(\mathrm{P}<0,01)$ terhadap vitamin $\mathrm{C}$ pada loloh don teter. Vitamin $\mathrm{C}$ pada perlakuan berkisar antara 23,00 $\mathrm{mg} / 100 \mathrm{ml}$ sampai dengan $26,39 \mathrm{mg} / 100 \mathrm{ml}$ dapat dilihat pada Tabel 2. Vitamin C tertinggi terdapat pada perlakuan P5 (konsentrasi buah asam 2,5\%) dan terendah pada perlakuan P0 (konsentrasi buah asam 0\%).

Vitamin $\mathrm{C}$ atau yang memiliki nama trivial asam askorbat memiliki sifat nutrasetikal karena bersifat sebagai antioksidan (Putra, 2020). Menurut Bhadoriya (2011) menyatakan bahwa daging buah asam mengandung senyawa asam seperti asam tartarat, asam askorbat, asam malat, asam sitrat, asam suknisat, dan asam asenat. Menurut Febrianti et al. (2015), melaporkan bahwa kandungan vitamin $\mathrm{C}$ yang terdapat dalam buah asam sebesar 41,06 mg/100g. Berdasarkan hasil penelitian ini kandungan vitamin $\mathrm{C}$ pada daun teter (P0) sebesar 23,00 $\mathrm{mg} / 100 \mathrm{ml}$, sehingga semakin banyak penambahan buah asam maka semakin tinggi juga kadar vitamin $\mathrm{C}$ loloh don teter.

\section{Aktivitas Antioksidan}

Hasil sidik ragam menunjukan bahwa pengaruh penambahan buah asam berpengaruh sangat nyata $(\mathrm{P}<0,01)$ terhadap aktivitas antioksidan pada loloh don teter. Nilai aktivitas antioksidan pada loloh don teter berkisar pada $32,28 \%$ sampai dengan $47,05 \%$ dapat dilihat pada Tabel 2. Aktivitas antioksidan tertinggi terdapat pada perlakuan P5 (konsentrasi buah asam 2,5\%) dan terendah 
pada perlakuan P0 (konsentrasi buah asam 0\%). Hal ini menunjukan bahwa semakin tinggi penambahan buah asam maka semakin tinggi juga aktivitas antioksidan pada loloh don teter. Aktivitas antioksidan dapat dipengaruhi oleh senyawa fenol dan flavonoid yang terkandung dalam daun teter dan buah asam pada loloh don teter. Aktivitas antioksidan akan meningkat apabila kandungan senyawa fenol dan flavonoid yang terdapat dalam bahan semakin tinggi, sehingga hal tersebut menunjukan adanya korelasi positif antara aktivitas antioksidan, fenol dan flavonoid (Prabandari, 2015). Selain itu, meningkatnya aktivitas antioksidan pada loloh don teter juga disebabkan oleh adanya kandungan vitamin C. Menurut Sukandar et al. (2014) vitamin C atau asam askorbat memiliki kemampuan sebagai antioksidan yang memiliki sifat larut dalam air. Vitamin C memiliki kolerasi yang selaras dengan dengan aktivitas antioksidan, semakin tinggi kadar vitamin $\mathrm{C}$ maka semakin tinggi juga aktivitas antioksidannya (Trisnawati et al., 2019).

Perlakuan dengan aktivitas antioksidan tertinggi yaitu pada P5 (penambahan buah asam 2,5\%) pada loloh don teter selanjutnya dilakukan uji $\mathrm{IC}_{50}$. Menurut Molyneux (2004) bahwa $\mathrm{IC}_{50}$ merupakan konsentrasi suatu zat antioksidan yang dapat menghambat radikal bebas sebanyak 50\%. Nilai $\mathrm{IC}_{50}$ yang diperoleh pada P5 yaitu sebesar 271.382,73 ppm. Semakin kecil nilai $\mathrm{IC}_{50}$ maka semakin tinggi aktivitas antioksidan yang terkandung dalam bahan begitu juga sebaliknya semakin besar nilai $\mathrm{IC}_{50}$ maka aktivitas antioksidan semakin rendah. Antioksidan yang terkandung dalam loloh don teter termasuk dalam katagori sangat lemah karena nilai $\mathrm{IC}_{50}>200 \mathrm{ppm}$.

\section{Total Padatan}

Hasil sidik ragam menunjukan bahwa perlakuan penambahan buah asam berpengaruh sangat nyata $(\mathrm{P}<0,01)$ terhadap total padatan yang terdapat pada loloh don teter. Nilai rata-rata total padatan pada loloh don teter berkisar antara $6,45 \%$ sampai dengan $7,44 \%$ dapat dilihat pada Tabel 2. Nilai total padatan tertinggi yaitu terdapat pada P5 (konsentrasi buah asam 2,5\%) dan terendah yaitu pada P0 (konsentrasi buah asam 0\%).

Total padatan merupakan semua komponen penyusun yang terdapat dalam loloh don teter (terlarut ataupun tidak terlarut) yang dikurangi dengan kadar air. Total padatan yang terdapat dalam loloh don teter diduga berasal dari residu daun teter dan buah asam. Menurut Tuhumury et al. (2016) melaporkan bahwa penambahan buah dalam formulasi dengan konsentrasi tertentu akan mempengaruhi total padatan akhir dari produk, total padatan akan meningkat seiring dengan penambahan konsentrasi buah. Berdasarkan penelitian ini bahwa buah asam memiliki zat terlarut yang lebih tinggi dibandingkan dengan daun teter sehingga 
semakin banyak penambahan buah asam maka semakin tinggi total padatan loloh don teter.

\section{Sifat Sensoris}

Pada penelitian ini evaluasi sensoris dilakukan dengan uji hedonik dan uji skoring. Uji hedonik dilakukan terhadap warna, aroma, rasa dan penerimaan keseluruhan, sedangkan uji skoring dilakukan terhadap rasa. Nilai ratarata uji hedonik terhadap warna, aroma, rasa, penerimaan keseluruhan dan uji skoring terhadap rasa loloh don teter dapat dilihat pada Tabel 3.

Tabel 3. Nilai rata-rata uji hedonik pada warna, aroma, rasa, penerimaan keseluruhan dan uji skoring rasa loloh don teter.

\begin{tabular}{|c|c|c|c|c|c|}
\hline \multirow{2}{*}{$\begin{array}{c}\text { Perlakuan } \\
\text { Buah Asam }\end{array}$} & \multicolumn{4}{|c|}{ Uji Hedonik } & \multirow{2}{*}{$\frac{\text { Uji Skoring }}{\text { Rasa }}$} \\
\hline & Warna & Aroma & Rasa & $\begin{array}{l}\text { Penerimaan } \\
\text { Keseluruhan }\end{array}$ & \\
\hline $\mathrm{P} 0(0 \%)$ & $3,80 \mathrm{ab}$ & $3,28 \mathrm{a}$ & $3,12 \mathrm{a}$ & $3,32 \mathrm{a}$ & $1,56 \mathrm{c}$ \\
\hline $\mathrm{P} 1(0,5 \%)$ & $4,00 \mathrm{a}$ & $3,48 \mathrm{a}$ & $3,72 \mathrm{a}$ & $3,76 \mathrm{a}$ & $2,08 \mathrm{~b}$ \\
\hline P2 (1\%) & $3,56 \mathrm{ab}$ & $3,68 \mathrm{a}$ & $3,92 \mathrm{a}$ & $3,96 \mathrm{a}$ & $2,44 a b$ \\
\hline P3 $(1,5 \%)$ & $3,40 \mathrm{abc}$ & $3,76 \mathrm{a}$ & $3,80 \mathrm{a}$ & $3,76 \mathrm{a}$ & $2,68 \mathrm{a}$ \\
\hline P4 (2\%) & $2,72 \mathrm{c}$ & $3,76 \mathrm{a}$ & $3,68 \mathrm{a}$ & $3,68 \mathrm{a}$ & $2,80 \mathrm{a}$ \\
\hline P5 $(2,5 \%)$ & $3,16 \mathrm{bc}$ & $3,68 \mathrm{a}$ & $3,64 \mathrm{a}$ & $3,80 \mathrm{a}$ & $2,88 \mathrm{a}$ \\
\hline terangan: & $\begin{array}{l}\text { edonik, } 5 \\
\text { g, } 4=\text { Sa } \\
\text { oleh hur } \\
\text { 5). }\end{array}$ & Agak & $\begin{array}{l}\text { sa; } 2= \\
\text { c Asaa } \\
\text { ig san }\end{array}$ & $\begin{array}{l}\text { dak Suka; 1 } \\
\text { dak Asam) } \\
\text { jukan perlak }\end{array}$ & $\begin{array}{l}\text { Suka) (Uji } \\
\text { a-rata yang } \\
\text { rbeda nyata }\end{array}$ \\
\hline
\end{tabular}

\section{Warna}

Hasil sidik ragam menunjukan bahwa perlakuan penambahan buah asam berpengaruh sangat nyata $(\mathrm{P}<0,01)$ terhadap warna loloh don teter dengan uji hedonik. Tabel 3 menunjukan bahwa nilai rata-rata warna pada uji hedonik oleh panelis berkisar antara 2,72 (biasa) sampai dengan 4,00 (agak suka). Nilai rata-rata kesukaan panelis terhadap warna loloh don teter tertinggi diperoleh pada perlakuan P1 (konsentrasi buah asam $0,5 \%$ ) dan berbeda tidak nyata dengan perlakuan P0, P2 dan P3. Sedangkan, nilai terendah diperoleh dari perlakuan P4 (konsentrasi buah asam 2\%) dan berbeda tidak nyata dengan P5. Menurut Winarno (2004) bahwa warna merupakan faktor penting dalam menentukan penerimaan suatu produk oleh konsumen karena tampilan visual yang pertama kali dilihat selain itu ada beberapa faktor lainnya antara lain cita rasa, aroma dan nilai gizinya.

\section{Aroma}

Hasil sidik ragam menunjukan bahwa perlakuan penambahan buah asam tidak berpengaruh nyata $(\mathrm{P}>0,05)$ terhadap aroma 
pada loloh don teter dengan uji hedonik. Tabel 3 menunjukan bahwa nilai rata-rata uji hedonik terhadap aroma loloh don teter berkisar antara 3,28 sampai dengan 3,76 dengan kriteria biasa hingga agak suka. Menurut Nagy dan Shaw (1980), asam jawa memiliki beberapa komponen volatil yang berperan dalam pembentukan aroma diantaranya 2 asetil furan, furfural, dan 5 metil furfural sehingga dihasilkan aroma asam jawa yang segar.

\section{Rasa}

Hasil sidik ragam menunjukan bahwa perlakuan penambahan buah asam tidak berpengaruh nyata $(\mathrm{P}>0,05)$ terhadap rasa pada loloh don teter dengan uji hedonik. Tabel 3 menunjukan bahwa nilai rata-rata uji hedonik terhadap rasa loloh don teter berkisar antara 3,12 sampai dengan 3,92 dengan kriteria biasa hingga agak suka. Hal ini menunjukan bahwa panelis dapat menerima rasa loloh don teter. Rasa merupakan salah satu faktor terpenting dalam penilaian suatu produk. Menurut Meilgaard et al. (2000) bahwa penilaian rasa dilakukan oleh indera pengecap rasa manusia ketika mengkonsumsi makanan atau minuman.

Berdasarkan hasil sidik ragam menunjukan bahwa perlakuan penambahan buah asam berpengaruh sangat nyata $(\mathrm{P}<0,01)$ terhadap rasa loloh don teter dengan uji skoring. Tabel 3 menunjukan bahwa nilai rata- rata uji skoring terhadap rasa loloh don teter berkisar antara 1,56 sampai dengan 2,88 dengan kriteria agak asam hingga asam. Menurut Heyne (1987) buah asam memiliki rasa asam manis menyegarkan yang berasal dari senyawa asam-asam organik yang terkandung di dalamnya seperti asam tartarat, asam sitrat, asam malat, asam suksinat dan asam asetat.

\section{Penerimaan Keseluruhan}

Hasil sidik ragam menunjukan bahwa perlakuan penambahan buah asam tidak berpengaruh nyata $(\mathrm{P}>0,05)$ terhadap penerimaan keseluruhan loloh don teter dengan uji hedonik. Tabel 3 menunjukan bahwa nilai rata-rata uji hedonik terhadap penerimaan keseluruhan loloh don teter berkisar antara 3,32 sampai dengan 3,96 dengan kriteria biasa hingga agak suka. Hal ini menunjukan bahwa panelis dapat menerima loloh don teter dari segi warna, aroma dan rasa.

\section{KESIMPULAN}

Perlakuan penambahan buah asam pada loloh don teter berpengaruh sangat nyata terhadap total fenol, total flavonoid, vitamin C, aktivitas antioksidan, total padatan, warna (uji hedonik), rasa (uji skoring) dan berpengaruh tidak nyata terhadap uji hedonik aroma, rasa dan penerimaan keseluruhan. Loloh don teter dengan karakteristik terbaik 
pada penelitian ini yaitu penambahan buah asam 2,5\% dengan karakteristik sebagai berikut : total fenol $0,86 \mathrm{GAE} / 100 \mathrm{ml}$, total flavonoid 0,48 QE/100ml, vitamin C 26,39 $\mathrm{mg} / 100 \mathrm{ml}$, aktivitas antioksidan 47,05\% dengan nilai $\mathrm{IC}_{50} 271.382,73 \mathrm{ppm}$, total padatan $7,44 \%$, warna biasa, aroma agak suka, rasa asam dan agak suka, dan penerimaan keseluruhan agak suka.

\section{DAFTAR PUSTAKA}

Anonimus. 2017. Terung Teter. https://id.wikipedia.org/wiki/Terung teter. Diakses pada 22 Desember 2019.

Bandawane D., H. Mayuri, dan M. Ashish. 2013. Nilam. Evaluation of anti-inflammatory and analgesic activity of tamarind (Tamarindus Indica L.) seeds. Int J Pharm Pharm Sci. 5: 623-629.

Bhadoriya S.B., A. Ganeshpurkar, J. Narwaria, G. Rai, dan A.P. Jain. 2011. Tamarindus indica: extent of explored potential. Pharmacognosy Reviews. 5: 73-81.

Essien E.E., I.A. Ogunwande, W.N. Setzer, dan O. Ekundayo. 2012. Chemical composition, antimicrobial, and cytotoxicity studies on $S$. erianthum and $S$. macranthum essential oils. Pharmaceutical Biology. 50(4): 474-480.

Ferrara, L. 2005. Antioxidant activity of Tamarindus indica L. Ingredient Alimentary. 4(6): 13-15.

Hayne, K. 1987. Tumbuhan Berguna Indonesia Jilid ke-3. Yayasan Serana Warna Jaya, Jakarta.

Mahadev R, H. Ramakrishnaiah, V. Krishna, K.N. Naveen, dan A.P. Deepalakshmi. 2015. In vitro antioxidant activity of methanolic extracts of Solanum erianthum D. Don. Inter J Pharm 5(1): 238-243.

Meilgaard, M., G.V. Civille, dan B.T. Carr. 2000. Sensory Evaluation Techniques. Boca Raton. CRC Press. Florida.
Miller, A.L. 1996. Antioxidant flavonoids: structure, function, and clinical usage. Alt Med Rev1:103 - 111

Modise, DM., dan KK, Mogotsi. 2008. Solanum erianthum D. Don. https://prota4u.org/database/protav8.asp?g $=p e \& p=$ Solanum\%20erianthum\%20D.Do n. (2 Januari 2020).

Molyneux, P., 2004. The use of the stable free radical diphenylpicryl-hydrazyl (DPPH) for estimating antioxidant activity, songklanakarin J. Sci. Technol. 26(2), 21121

Nagy S, Shaw PE. 1980. Tropical and SubTropical Fruits, Composition, Properties, and Uses. Westport: The AVI Publishing Co. Inc

Prabandari, I. M. 2015. Pengaruh Lama Penyimpanan dan Perebusan Daun Sirsak Segar (Annona muricata Linn) Terhadap Aktivitas Antioksidan Sari Daun Sirsak. Skripsi. Fakultas Teknologi Pertanian. Institut Pertanian, Bogor.

Priyadharsini S.D, Sujatha V. 2013. Antioxidant profile and GC-MS analysis of $S$. erianthum leaf and stem, a comparison. Int J Pharm and Pharm Sci 5(3): 652-658.

Purnomo, L., S Surjoseputro dan E Setijawati. 2018. Pengaruh Konsentrasi Buah asam (Tamarindus indica L.) terhadap Sifat Fisikokimia dan Organoleptik Leather Pulp Kulit Pisang Kepok-Buah asam. Skripsi. Tidak Dipublikasikan. Fakultas Teknologi Pertanian, Universitas Katolik Widya Mandala. Surabaya.

Putra, I.N.K. 2020. Substansi Nutrasetikal Sumber dan Manfaat Kesehatan. Deepublish. Sleman.

Septiana, A.T. Kadar dan aktivitas antioksidan minuman kunyit dan asam yang manis. 2014. Agritech. 24(2): 92-95.

Steel, R. G. D Dan J. H. Torrie. 1993. Prinsip Dan Prosedur Statistika Suatu Pendekatan Biometrik. Penerjemah B. Sumantri. Pt. Gramedia Pustaka, Jakarta.

Sudjaroen, Y., Haubner, R., Wurtule, G., Hull, W.E, Erben, G., Spiegelhalder, B., Changbumrung, S., Bartsch, H., Owen, R.W. 2005. Isolation and structure elucidation of phenolic antioxidants from 
tamarind (Tamarindus indica L.) seeds and pericarp. Food Chem. Toxicol. 43: 16731682.

Sukandar, D., A. Muawanah, E.R. Amelia, dan F.N. Anggraeni. Aktivitas antioksidan dan mutu sensori formulasi minuman fungsional sawo-kayu manis. 2014. Jurnal Kimia Valensi. 4(2): 80-89.

Suryadarma, I.G.P. 2005. Konsepsi kosmologi dalam pengobatan usada taru pramana. Journal of Tropical Ethnobiology. 2(1): 6587.

Trisnawati, I., W. Hersoelistyorini, dan Nurhidajah. Tingkat kekeruhan, kadar vitamin c, dan aktivitas antioksidan infused water lemon dengan variasi suhu dan waktu perebusan. 2019. Jurnal Pangan dan Gizi. 9(1): 27-38.
Tuhumury, H.C.D., S.J. Nendissa, dan M. Rumra. 2016. Kajian sifat fisikokimia dan organoleptic es krim pisang tongka langit. Jurnal Teknologi Pertanian. 5(2): 46-52.

Wijayanti, R.K., W.D.R. Putri dan N.I.P. Nugrahini. Pengaruh proporsi kunyit (Curcuma longa L.) dan asam jawa (Tamarindus indica) terhadap karakteristik leather kunyit asam. 2016. Jurnal Pangan dan Agroindustri. 4(1): 158-169.

Winarno, F.G. 2004. Hasil-hasil symposium penganekaragaman pangan. Prakarsa Swasta dan Pemda. Jakarta.

Wirati, W., 2019. Pembuatan Loloh Don Teter (Solanum erianthum). Wawancara. Gianyar. 